\begin{tabular}{l|l|l} 
Jurnal Eksplorasi Akuntansi & $\begin{array}{l}\text { ISSN : 2656-3649 (Online) } \\
\text { Vol 2, No 3, Seri D, Agustus 2020, Hal 3312-3326 }\end{array}$
\end{tabular}

\title{
PENGARUH KOMPETISI POLITIK, PENDAPATAN ASLI DAERAH, DANA ALOKASI UMUM, DAN OPINI AUDIT TERHADAP IMPLEMENTASI E-GOVERNMENT
} (Studi Empiris Pada Provinsi di Indonesia Tahun 2011-2018)

\author{
Sonia Oktaviani ${ }^{1}$, Fefri Indra Arza ${ }^{2}$ \\ 1)Alumni Jurusan Akuntansi Fakultas Ekonomi Universitas Negeri Padang \\ 2) Jurusan Akuntansi Fakultas Ekonomi Universitas Negeri Padang \\ *Korespondensi: soniaoktaviani11@gmail.com
}

\begin{abstract}
This study aims to determine the effect of political competition, local own-source revenue, general allocation funds, and audit opinions on the implementation of provincial $e$ Governments in Indonesia in 2011-2018. Data in this study uses secondary data from BPK, BPS, and KPU. The sampling technique uses a purposive sampling method with a total sample of 8 provinces in 5 years. Data analysis uses regression analysis. The results of this study indicate that (1) political competition has a negative and insignificant influence on e-government implementation, (2) Local original income has a positive and significant effect on e-government implementation, (3) general allocation funds have a positive and not significant effect on implementation e-government. (4) audit opinion does not significantly influence the implementation of e-government.
\end{abstract}

Keywords: e-government, political competition, local revenue, general allocation fund, audit opinion

How to cite (APA 6 $^{\text {th }}$ style):

Oktaviani, Sonia \& Arza, F.I (2020). Pengaruh Kompetisi Politik, Pendapatan Asli Daerah, Dana Alokasi Umum, dan Opini Audit Terhadap Implementasi E-Government (Studi Empiris pada Provinsi di Indonesia Tahun 2011-2018). Jurnal Eksplorasi Akuntansi, 2(3), Seri D, 3312-3326.

\section{PENDAHULUAN}

E-Government merupakan suatu upaya untuk memanfaatkan teknologi informasi dan komunikasi yang dimaksudkan untuk meningkatkan efisiensi, efektivitas, transparansi, akuntabilitas, penyelenggaraan pemerintahan dan pelayanan publik. Indonesia merupakan salah satu Negara yang telah menggunakan internet dalam menyampaikan informasi serta pelayanan dari pemerintah kepada masyarakat. Namun, Indonesia masih selalu melakukan pembenahan dan pembaruan agar E-government dapat berjalan dengan lebih baik lagi. 
Banyaknya praktek maladministrasi serta masih lemahnya respon pemerintah pada tiap pelayanan yang ada menjadikan ini sebagai pembenahan implementasi E-government. (Publik \& Nurmandi, 1997). Tujuan implementasi e-government adalah untuk mewujudkan, menerapkan, transparansi dan akuntabilitas publik yang lebih baik dari sebelumnya. Namun, dalam pelaksanaannya masih selalu mengalami perkembangan dan pembaruan. Persoalan mendasar di dalam penyelenggaran e-government tersebut yaitu pertama, pemerintah daerah otonom masih bersifat sendiri-sendiri dalam inisiatif dan memaknai implementasi e-government. Kedua, kurangnya peraturan, system manajemen, pekerja yang mahir dalam teknologi informasi, serta proses kerja yang tidak memadai. Ketiga, pemerintah masih berfikir bahwa implementasi $e$ government tidak terlalu penting, dan hanya syarat dalam pelaksanaan saja (Sipatuhur \& Sutaryo, 2016).

Terdapat lima kegunaan e-government dalam instansi pemerintahan, yaitu (1) kegunaan layanan untuk mempermudah masyarakat, (2) mencari dan memperoleh informasi umum, (3) pencarian informasi untuk kebijakan, (4) pengambilan keputusan oleh masyarakat, (5) cocreation: menyusun kebijakan, informasi, dan layanan-layanan oleh pemerintah dan warga negara secara bersama-sama (Nam, 2014). Kementerian Komunikasi dan Informatika (MENKOMINFO) mengadakan pemeringkatan e-government berdasarkan 5 kriteria untuk mengukur dan mengetahui perkembangan implementasi e-government di Indonesia. Lima kriteria tersebut adalah kebijakan, kelembagaan, infrastruktur, aplikasi dan perencanaan. Jika di lihat dari pemeringkatan E-Governement Indonesia (PeGI) Implementasi e-government tingkat provinsi tahun 2012 hingga tahun 2015 masih banyak provinsi yang memperoleh kriteria kurang dan di harapkan agar provinsi yang memperoleh kriteria kurang dapat melakukan perkembangan dalam implementasi e-government.

Fenomena mengenai implementasi E-Government di Indonesia adalah Pertama, terbatasnya regulasi atau payung hukum. Kedua, tidak maksimalnya penerapan e-government pada institusi pemerintah yang di karenakan kurangnya tenaga ahli yang kompeten di bidang teknik informatika. Ketiga, belum terintegrasinya data antar instansi pemerintahan juga menjadi kendala dalam penerapan e-government. Berdasarkan masalah tersebut maka Kepala Biro Hukum, Komunikasi, dan Informasi dan Publik Kementerian Pendayagunaan Aparatur Negara dan Reformasi Birokrasi (PAN-RB) Herman Suryatman memberikan solusi yakni pencepatan program pembangunan satu data, pembentukan payung hukum penerapan e-government dan peningkatan keamanan informasi untuk seluruh level secara berkesenambungan. Adanya forum rutin antar instansi pemerintahan untuk membahas pengembangan e-government juga di perlukan (Jakarta Kompas.com, 2016).

Implementasi e-government yaitu pengungkapan melalui website pemerintahan daerah. Pengungkapan dalam website pemerintahan tersebut tidak hanya pengungkapan tentang laporan keuangan saja tetapi termasuk pengungkapan informasi non keuangan. Variabel independen yang di gunakan dalam penelitian ini adalah kompetisi politik, pendapatan asli daerah, dan opini audit. E-government dalam penerapannya membutuhkan biaya yang besar. Hal ini memungkinkan jika kesejahteraan ekonomi daerah sudah baik, pemerintah akan mempunyai biaya yang cukup untuk melayani masyarakat melalui implementasi e-government (Sipatuhur \& Sutaryo, 2017) . Menurut (Christaens, 1999), kinerja yang tinggi merupakan sinyal dari manajemen publik yang baik. Sedangkan penelitian (Craven \& Marston, 1999) menunjukkan bahwa Pemda yang buruk akan menghindari pengungkapan sukarela seperti voluntary internet based disclosure dan akan memilih membatasi pengungkapan informasi bagi masyarakat. 
(Rahim \& Martani, 2015), dan (Sipatuhur \& Sutaryo, 2016) menemukan bahwa PAD berpengaruh positif terhadap implementasi e-government.

Isu e-governance cukup relevan diteliti dalam konteks propinsi Sumatera Barat, mengingat dalam sejumlah publikasi riset terlihat bahwa pemerintah belum sepenuhnya menyikapi hal ini. Sebagai contoh, riset Agustin (2014) menemukan bahwa mayoritas pemerintah kabupaten dan kota di propinsi Sumatera Barat enggan menggunakan website resminya masing-masing untuk mempublikasikan dokumen-dokumen pengelolaan anggaran. Riset Agustin dan Arza (2019) menemukan anomali antara akuntabilitas dan transparansi publik terkait dengan manajemen pengelolaan keuangan daerah. Akuntabilitas publik pemerintah daerah meningkat, dimana pemerintah kabupaten dan kota di propinsi Sumatera Barata cukup sering menggunakan website resmi pemda untuk menggunggah opini BPK atas laporan keuangan pemerintah daerah (LKPD). Namun, disisi lain akuntabilitas publik masih relatif rendah, mengingat pada website yang sama dokumen-dokumen terkait pengelolaan anggaran relatif minim ditemukan.

Opini audit ialah pernyataan profesional pemeriksa mengenai kewajaran informasi keuangan yang disajikan dalam laporan keuangan berdasarkan pada kriteria, kesesuaian dengan standar akuntansi pemerintahan, kecukupan pengungkapan (adequate disclosure), kepatuhan dalam melaksanakan peraturan perundang undangan dan efektifitas sistem pengendalian internal (Faud, 1999). Implementasi E-Government dapat mempengaruhi akuntabilitas dan transparansi salah satunya dengan pengungkapan melalui website daerah. Hal ini di disebabkan informasi yang di sajikan oleh pemerintah daerah dapat di peroleh secara mudah oleh masyarakat dan masyarakatpun dapat menikmati secara terbuka. Hal ini didukung oleh penelitian (Rahim \& Martani, 2015) yang menemukan opini audit memiliki hubungan positif terhadap pengungkapan informasi keuangan pada website pemerintah daerah secara signifikan.

Ketersediaan suatu informasi dan kemudahan dalam memperoleh informasi untuk publik merupakan salah satu peningkatan transparansi. Melaksanakan keterbukaan informasi keuangan publik menggunakan media elektronik ialah situs resmi yaitu salah satu cara yang paling efektif dalam melaksanakan keterbukaan informasi keuangan publik. Penelitian terdahulu yang relevan dengan penelitian ini yang menunjukkan bahwa kompetisi politik tidak berpengaruh signifikan terhadap implementasi e-government, PAD berpengaruh siginifikan terhadap implementasi $e$ government, dan Opini audit tidak memiliki pengaruh signifikan terhadap implementasi $e$ government (Utami, 2017).

Penelitian ini berbeda dengan penelitian sebelumnya. Pertama, Penambahan variabel yaitu Dana Alokasi Umum dengan alasan bahwa adanya dana dari pemerintah pusat mengakibatkan pemerintah daerah harus mengelola dengan sebaik-baiknya dana tersebut. Sehingga, diharapkan jika DAU tinggi berarti pemerintah kota memiliki tingkat ketergantungan yang tinggi kepada pemerintah pusat dan begitu sebaliknya yang mengakibatkan pemerintah pusat harus mempertanggung jawabkan dana yang telah di berikan oleh pemerintah pusat tersebut salah satu alokasi dana nya adalah dengan meningkatkan implementasi e-government.

Kedua, periode penelitian yang berbeda dari penelitian terdahulu, yaitu periode penelitan dari tahun 2011-2018. Sehingga peneliti tertarik untuk melakukan penelitian pada Pemerintah Provinsi Jawa Barat dan peneliti menetapkan judul "Pengaruh Kompetisi Politik, PAD, DAU dan Opini Audit terhadap Implementasi E-Government (Studi empiris pada pemerintah pripinsi di Indonesia)". 


\section{REVIU LITERATUR DAN PENGEMBANGAN HIPOTESIS Teori Keagenan}

Teori keagenan (agency theory) menyatakan bahwa hubungan agensi ada ketika satu orang atau lebih (principal) mempekerjakan orang lain (agent) dalam memberikan suatu jasa kemudian mendelegasikan wewenang pengambilan keputusan kepada agent tersebut (Jensen \& Meckling, 1979) . Berkaitan dengan teori agensi dimana masyarakat sebagai prinsipal dan calon kepala daerah sebagai agen, para politikus mengharapkan mendapatkan suara pemilih dari masyarakat lebih banyak, sehingga mereka berusaha untuk memenuhi kebutuhan masyarakat pemilih yang telah memilih (Al-Naimat, 2014).

Dalam penelitian ini masyarakat sebagai principal dan para anggota dewan sebagai agent, dimana para politikus mengharapkan mendapatkan suara pemilih dari masyarakat lebih banyak, sehingga mereka berusaha untuk memenuhi kebutuhan masyarakat yang akan memilih. Selanjutnya pemerintah daerah sangat bertanggungjawab untuk melaporkan hasil kinerjanya kepada masyarakat. Agent yang telah terpilih adalah agent yang telah di percayai oleh masyarakat dalam mengelola dan memimpin masyarakat dan daerahnya oleh karena itu agen berkewajiban untuk melaporkan hasil kinerjanya selama satu periode agar masyarakat dapat merasa puas dan percaya terhadap agent.

\section{Teori Stewardship}

Dalam penelitian ini, peneliti menggunakan teori stewardship, dimana pemerintah sebagai steward dan masyarakat sebagai principal. Steward menjalankan tugasnya untuk kepentingan organisasi tidak untuk kepentingan pribadi, sehingga dalam melakukan publikasi informasi non keuangan atau keuangan yaitu laporan keuangan adalah bentuk tanggung jawab steward dalam menjalankan amanah dari pihak principal. Pemerintah daerah dengan sebiak-baiknya dapat memaksimalkan PAD untuk melengkapi sarana dan prasarana di daerah tersebut, sehingga tercapailah kesejahteraan masyarakat.

\section{Teori Signalling}

Jika dikaitkan dengan penelitian ini, pemerintah daerah bertanggung jawab memberikan informasi atau sinyal pada masyarakat untuk memberikan keyakinan yang memadai kepada masyarakat. Bertujuan untuk masyarakat dapat terus mendukung pemerintah yang saat ini selalu berjalan dengan baik. Salah satu caranya keunggulan internet dengan fasilitas e-government seperti ini dapat didistribusikan lebih cepat dan dapat dieksploitasi untuk lebih membuka diri dengan menginformasikan laporan keuangannya kepada masyarakat secara mudah.

\section{E-Government}

E-government ialah suatu upaya untuk memanfaatkan teknologi informasi dan komunikasi yang dimaksudkan untuk meningkatkan efisiensi, efektivitas, transparansi, akuntabilitas penyelenggaraan pemerintahan dan pelayanan publik. Bersamaan dengan dikeluarkannya (Instruksi Presiden No.3 , 2003) Tentang Kebijakan dan Strategi Nasional Pengembangan EGovernment menjadi tantangan baru bagi pemerintah daerah untuk memberikan pelayanan yang cepat dan akurat karena pemanfaatan teknologi informasi dan komunikasi (TIK) akan menjadikan sistem informasi di dalam pemerintah daerah terhubung secara online sehingga masyarakat dapat memperoleh layanan yang cepat, tepat, mudah, dan lebih akurat dalam perolehan informasi yang nantinya akan berguna untuk masyarakat. 
Maka dapat di simpulkan bahwasanya E-Government sangat berguna sekali bagi pemerintah daerah, terutama lagi dalam pengungkapan informasi keuangan atau non keuangan, dimana melalui E-Government ini pemerintah dapat memafaatkan akses internet dalam pengungkapannya dengan begitu masyarakatpun akan dengan mudah dalam memperoleh informasi yang di butuhkannya. E-Government juga dapat meningkatkan efisiensi, efektivitas, transparansi, akuntabilitas penyelenggaraan pemerintahan dan pelayanan publik.

\section{Hubungan Antara Kompetisi Politik Terhadap Implementasi E-Government}

Kompetisi politik ialah kompetisi atau disebut daya saing untuk dapat menduduki jabatan di suatu pemerintahan. Kompetisi politik pada penelitian ini di lihat dari jumlah persentase kemenangan dalam pemilihan kepala daerah terakhir pada setiap provinsi di Indonesia. Presentase yang tinggi berarti menunjukkan bahwa calon terpilih memenuhi keinginan masyarakat lebih besar dari pada calon yang tidak terpilih. Hal ini akan menyebabkan kompetisi polittik menjadi lebih tinggi, terutama untuk mempertahankan posisi kepala daerah dalam periode berikutnya. Utami dalam penelitiannya menyebutkan banyaknya perangkat yang berhasil terlibat dalam posisi strategis dapat mengindikasikan adanya semangat yang besar dan tingkat pengawasan yang tinggi dalam mengoptimalkan kinerja pemerintah (Utami, 2017).

Kepala daerah ialah pemerintah yang memiliki peran terkait pengawasan keuangan daerah yang mengontrol kebijakan keuangan daerah secara tarnasparansi dan akuntabel serta efektif, efisien, dan ekonomis. Pengawasan tersebut terkait operasional pemerintahan dan termasuk pengawasan dalam melaksanakan implementasi e-government. Kepala daerah yang terpilih biasanya akan berusaha untuk memajukan daerah mereka salah satunya adalah penerapan e-governement atau mengembangkan e-government yang sudah ada agar menjadi lebih baik lagi sehingga tercipta good government. Berdasarkan uraian di atas, maka penelitian ini mengajukan hipotesis sebagai berikut :

H1: Kompetisi politik berpengaruh signifikan positif terhadap Implementasi E-Governement.

\section{Hubungan Antara Pendapatan Asli Daerah Terhadap Implementasi E-Government}

Pendapatan asli daerah ialah salah satu sumber utama yang di gunakan oleh pemerintah daerah untuk menjalankan pemerintahan nya dimana bertujuan untuk mngembangkan daerah tersebut, sehingga pemenuhan sarana dan prasarana dalam rangka pembangunan daerah dipengaruhi oleh besarnya pendapatan yang di peroleh. E-government dalam penerapannya biasanya membutuhkan biaya yang besar. Hal ini memungkinkan bahwasanya jika kesejahteraan ekonomi daerah sudah baik, pemerintah akan mempunyai biaya yang cukup dalam pembiayaan untuk melayani masyarakat melalui implementasi e-government (Sipatuhur \& Sutaryo, 2017). Oleh karena itu, kepala daerah yang telah menjabat di suatu daerah akan berusaha untuk memperoleh PAD yang besar untuk melakukan pembangungan agar tercapainya kesejahteraan masyarakat. Berdasarkan uraian di atas, maka penelitian ini mengajukan hipotesis sebagai berikut :

H2:Pendapatan asli daerah berpengaruh signifikan positif terhadap Implementasi $E$ Governement.

\section{Hubungan Antara Dana Alokasi Umum Terhadap Implementasi E-Government}

Dana alokasi umum adalah sejumlah dana yang di alokasikan pemerintah pusat kepada setiap pemerintah daerah otonom seperti provinsi, kabupaten, kota di Indonesia setiap tahunnya. Tujuan adanya transfer DAU ialah sebagai pemerataan kemampuan keuangan antar setiap daerah untuk mendanai kebutuhan daerah otonom dalam rangka pelaksanaan desentralisasi. Dana Alokasi 
Umum yang telah di bagikan pada setiap daerah dapat di gunakan untuk pengImplementasi $E$ Government pada setiap pemerintahan, sehingga semakin besar dana alokasi umum pada suatu daerah itu seharusnya bisa memiliki implementasi e-government yang baik. Berdasarkan uraian di atas, maka penelitian ini mengajukan hipotesis sebagai berikut :

H3: Dana Alokasi Umum berpengaruh signifikan positif terhadap Implementasi E-Governement.

\section{Hubungan Antara Opini Audit Terhadap Implementasi E-Government}

Berdasarkan undang-undang, terdapat 4 empat jenis opini BPK atas laporan keuangan pemerintah yaitu, Wajar Tanpa Pengecualian (WTP), Wajar Dengan Pengecualian (WDP), Tidak Wajar (TW), dan Tidak Memberikan Pendapat (TMP). Selain itu BPK juga memberikan opini lain yaitu opini wajar tanpa pengecualian dengan paragraf penjelas (Undang-Undang Nomor 15 Tahun 2004 Pasal 16 Ayat 1).

Opini WTP yang di peroleh menggambarkan bahwasanya daerah tersebut memiliki salah saji materiil yang lebih sedikit dan menggambarkan bahwasanya daerah tersebut dapat menyusun laporan keuanganya dengan lebih cepat dan dapat mempublikasikan dengan cepat pula. Hal ini dapat di katakan bahwasanya pemerintahan yang telah mendapat opini WTP berarti bahwa pemerintahan tersebut telah menerapkan pemerintahan yang baik atau dapat di katakan good government. Sehingga, tentunya pemerintahan yang memperoleh WTP cenderung akan mengungkapkan informasinya lebih banyak lagi.Berdasarkan uraian di atas, maka penelitian ini mengajukan hipotesis sebagai berikut :

H4: Opini Audit berpengaruh signifikan positif terhadap Implementasi E-Governement.

\section{METODE PENELITIAN}

Jenis penelitian yang digunakan oleh peneliti ialah penelitian kausatif. Penelitian kausatif memiliki tujuan untuk menganalisis pengaruh suatu variabel terhadap variabel lainnya. Pendekatan yang dilakukan dalam penelitian ini ialah pendekatan atau metode kuantitatif.

\section{Populasi dan Sampel}

Populasi dalam penelitian ini yaitu pemerintah Provinsi di Indonesia. Jumlah provinsi di Indonesia ialah 34 Provinsi. Sampel di peroleh dengan menggunakan metode purposive sampling. Purposive sampling ialah menentukan sampel dari populasi berdasarkan beberapa kriteria yang di pilih penulis. Kriteria yang di gunakan adalah sbb, 1).Pemerintah provinsi yang sudah melaporkan laporan keuangan ke BPK tahun 2011-2018. 2).Pemerintah provinsi yang telah dilakukan Pemeringkatan e-Government tahun 2011-2018. 3).Pemerintah provinsi yang menyediakan informasi yang lengkap sesuai kebutuhan penelitian.

\section{Jenis, Sumber dan Teknik Pengumpulan Data}

Jenis data yang digunakan dalam penelitian ini yaitu merupakan jenis data sekunder. Sumber data dari penelitian ini ialah dari APBD yang dijelaskan oleh (Direktorat Jenderal Bina Keuangan Daerah Kementrian Dalam Negeri), laporan keuangan pemerintah daerah, serta opini mengenai daerah tersebut yang informasinya dapat dilihat di Badan Pemeriksa Keuangan ( BPK ), Badan Pusat Statistik ( BPS ) perwakilan setiap provinsi 2011 sampai dengan tahun 2015, persentasi kemenangan politik di peroleh dari situs resmi KPU setiap provinsi. 


\section{Variabel Penelitian dan Pengukuran}

Variabel dependen dalam penelitian ini ialah implementasi e-government. Kementerian komunikasi dan informasi atau KOMINFO telah melakukan pemeringkatan e-government indonesia (P-eGi). Dari tahun 2007 pertama kali melakukan pemeringkatan sampai 2017 kominfo menemukan hasil bahwa yaitu masih banyak sekali daerah yang memperoleh kriteria KURANG dalam melakukan pengimplementasian e-government. Hanya beberapa provinsi yang selalu memperoleh kategori BAIK dalam pelaksanaan P-eGi. Ini berarti bahwa masih banyaknya daerah yang kurang dalam pengimplementasian e-government.

Implementasi E-Government di ukur dengan menggunkan Pemeringkatan e-Government Indonesia, dinilai dengan menggunakan lima komponen sebagai berikut: kebijakan, kelembagaan, infrastruktur, aplikasi dan perencanaan. Kategori nilai dalam pemeringkatan e-government Indonesia ini adalah 1,0 - 1,49 dikategorikan sangat kurang, 1,5 - 2,49 dikategorikan kurang, 2,5 - 3,49 dikategorikan baik, dan 3,5 - 4,0 dikategorikan sangat baik. Variabel independen dalam penelitian ini yaitu Kompetisi politik, pendapatan asli daerah, dan opini audit. Berikut pengukuran variabel bebas dalam penelitian ini :

a) Kompetisi Politik

Kompetisi politik diukur dengan menggunakan nilai 1-persentase kemenangan dalam pemilihan kepala daerah terakhir pada setiap provinsi (rahim \& martani , 2016).

b) Pendapatan Asli Daerah

$$
\text { Kompetisi Politik }=1-\% \text { Kemenangan Pilkada }
$$

Pendapatan Asli Daerah (PAD) di ukur dengan menggunakan logaritma natural (Ln PAD) yang merupakan total pendapatan asli daerah yang diterima daerah di setiap tahunnya.

$\mathrm{PAD}=$ Pajak daerah + Retribusi daerah + Hasil pengelolaan kekayaan negara yang dipisahkan + lainlain pendapatan asli daerah yang sah.

c) Dana Alokasi Umum

Dana Alokasi Umum (DAU) diukur dengan melihat angka realisasi DAU dari pemerintah provinsi di Indonesia pada tahun 2011 sampai 2018 dengan menggunakan nominal mata uang Indonesia yaitu rupiah (Rp).

d) Opini Audit

Opini audit di ukur dengan menggunakan variabel dummy dengan ketentuan: $1=$ WTP $0=$ non WTP.

\section{Metode Analisis Data}

Analisis data yang digunakan dalam penelitian ini merupakan analisis deskriptif dan analisis regresi. Analisis regresi ialah aplikasi yang di gunakan untuk menganalisis regresi linier berganda, dimana nantinya dalam persamaan regresinya mengandung adanya unsur perkalian dua atau lebih variabel. Adapun persamaan reresinya adalah sebagai berikut:

Keterangan:

$$
\mathrm{Y}=\alpha+\beta 1 \mathrm{X} 1+\beta 2 \mathrm{X} 2+\beta 3 \mathrm{X} 3+\beta 3 \mathrm{X} 4+\mathrm{e}
$$

$\mathrm{Y}=$ Implementasi e-government

$\alpha=$ Konstanta

$\beta 1, \beta 2, \beta 3, \beta 4=$ Koefisien ragresi masing-masing variabe independen

$\mathrm{X} 1=$ Kompetisi Politik

X2 = Pendapatan Asli Daerah 
X3 = Dana Alokasi Umum

X4 = Opini Audit

$\mathrm{e}=$ Error term

\section{HASIL DAN PEMBAHASAN}

\section{Gambaran Umum Objek Penelitian}

Objek penelitian pada penelitian ini yaitu pemerintah provinsi yang ada di Indonesia dengan jumlah 34 provinsi di Indonesia. Sampel dalam penelitian ini di peroleh dengan menggunakan teknik purposive sampling sehingga total sampel yang di peroleh dan dapat di olah adalah 9 Provinsi di Indonesia

\section{Statistik Deskriptif}

Tabel 1

Analisis Deskriptif

\begin{tabular}{lrrrrrr}
\hline \multicolumn{7}{c}{ Descriptive Statistics } \\
\hline & $\mathrm{N}$ & Minimum & Maximum & Sum & Mean & $\begin{array}{c}\text { Std. } \\
\text { Deviation }\end{array}$ \\
\hline E-Government & 40 & 1.61 & 3.39 & 104.40 & 2.6100 & .47064 \\
\hline $\begin{array}{l}\text { Kompetisi } \\
\text { Politik }\end{array}$ & 40 & .41 & .68 & 22.49 & .5624 & .10194 \\
\hline PAD & 40 & 27.00 & 31.00 & 1153.00 & 28.8250 & 1.19588 \\
\hline DAU & 39 & 25.00 & 31.00 & 1136.00 & 29.1282 & 1.37992 \\
\hline Opini Audit & 40 & .00 & 1.00 & 31.00 & .7750 & .42290 \\
\hline $\begin{array}{l}\text { Valid N } \\
\text { (listwise) }\end{array}$ & 39 & & & & & \\
\hline Sumber: Data diolah spss tahun 2020 & & & & & & \\
\hline
\end{tabular}

Sumber: Data diolah spss tahun 2020

Berdasarkan tabel diatas, kompetisi politik sebagai variabel X1 mempunyai nilai rata-rata 0,056 sedangkan nilai tertinggi sebesar 0,068 dan nilai terendah sebesar 0,041. Kemudian untuk variabel X2 yaitu PAD memiliki nilai rata-rata sebesar 0,28 sedangkan nilai tertinggi sebesar 0,31 dan nilai terendah sebesar 0,27. Variabel X3 yaitu DAU memiliki rata-rata sebesar 0,29 sedangkan nilai tertinggi sebesar 0,31 dan nilai terendah yaitu 0,25. Opini audit yang merupakan variabel X4 memiliki nilai rata-rata 0,077 sedangkan nilai tertinggi yaitu 0,1 dan nilai terendah 0.00 .

\section{Uji Multikolinearitas}

Uji multikolinearitas ialah pengujian bertujuan untuk melihat apakah pada model regresi di temukan adanya korelasi antara variabel bebas (independen). Model regresi yang baik seharusnya tidak terjadi korelasi antara variabel independen. 
Tabel 2

Uji Multikolinearitas

\section{Coefficients $^{\mathrm{a}}$}

\begin{tabular}{ccccc}
\hline & & \multicolumn{2}{c}{ Collinearity Statistics } \\
\cline { 3 - 5 } \cline { 3 - 4 } 1 & Model & Sig. & Tolerance & VIF \\
\cline { 2 - 5 } & (Constant) & .158 & & \\
\cline { 2 - 5 } & Kompetisi Politik & .840 & .752 & 1.330 \\
\cline { 2 - 5 } & PAD & .001 & .838 & 1.193 \\
\hline DAU & .690 & .796 & 1.256 \\
\hline
\end{tabular}

a. Dependent Variable: E-Government

Sumber : Data diolah spss tahun 2020

Berdasarkan tabel 2 di atas coefficient pada bagian collinearity statistics di ketahui nilai tolerance seluruh variabel independen yang terdiri dari nilai diatas atau lebih besar $>$ dari 010 sedangkan untuk nilai VIF pada keseluruhan variabel independen terlihat bahwasannya untuk keseluruhan variabel independen mempunyai nilai VIF yang terdiri dari nilai dibawah atau lebih kecil < dari 10,00, maka berdasarkan pengambilan keputusan dalam uji multikolineritas dapat disimpulkan bahwa tidak terjadi gejala multikolineritas dalam model regresi.

\section{Uji Multikolinieritas}

Uji multikolonieritas bertujuan untuk menguji apakah pada model regresi di temukan adanya korelasi antara variabel bebas (independen). Model regresi yang baik apabila tidak terjadi korelasi antara variabel independen.

Tabel 3

Tabel Multikolinieritas

\begin{tabular}{lllll}
\hline \multirow{2}{*}{ Model } & & \multicolumn{2}{c}{ Collinearity Statistics } \\
\cline { 3 - 5 } 1 & Sig. & Tolerance & VIF \\
\cline { 2 - 5 } & (Constant) & .158 & & \\
\cline { 2 - 5 } Kompetisi Politik & .840 & .752 & 1.330 \\
\cline { 2 - 4 } & PAD & .001 & .838 & 1.193 \\
\cline { 2 - 4 } & DAU & .690 & .796 & 1.256 \\
\cline { 2 - 4 } & Opini Audit & .314 & .888 & 1.126 \\
\hline
\end{tabular}

a. Dependent Variable: E-Government

Sumber : Data diolah spss tahun 2020

Berdasarkan tabel 3 di atas coefficient pada bagian collinearity statistics di ketahui nilai tolerance seluruh variabel independen yang terdiri dari nilai diatas atau lebih besar $>$ dari 010 sedangkan untuk nilai VIF pada keseluruhan variabel independen terlihat bahwasannya untuk keseluruhan variabel independen mempunyai nilai VIF yang terdiri dari nilai dibawah atau lebih kecil < dari 10,00, maka berdasarkan pengambilan keputusan dalam uji multikolineritas dapat disimpulkan bahwa tidak terjadi gejala multikolineritas dalam model regresi. 


\section{Uji Heteroskedastisitas}

Uji heterokedastisitas ialah uji untuk mengetahui terjadinya varian yang tidak sama untuk variabel bebas yang berbeda. jika variance dari residual satu pengamatan ke pengamatan lain berbeda (heterokedastisitas) maka dapat di katakana model regresi yang baik.

\begin{tabular}{llrrrr}
\hline \multicolumn{6}{c}{ del Summary } \\
\hline Model & R & R Square & $\begin{array}{c}\text { Adjusted R } \\
\text { Square }\end{array}$ & $\begin{array}{l}\text { Std. Error of } \\
\text { the Estimate }\end{array}$ \\
\hline 1 & $.607^{\mathrm{a}}$ & .369 & .294 & .38576 \\
\hline
\end{tabular}

a. Predictors: (Constant), Opini Audit, PAD, Kompetisi Politik, DAU

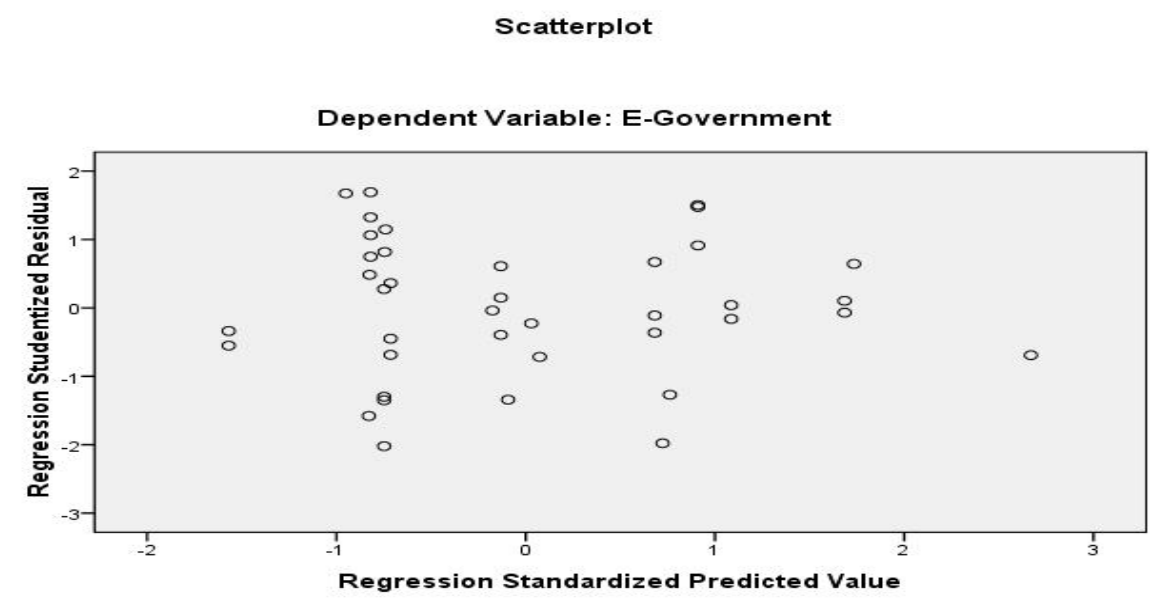

Gambar 1. Hasil Uji Heteroskedastisitas

Sumber : Data diolah spss tahun 2020

Berdasarkan hasil output scatterplots pada gambar 1.1 diketahui bahwasannya titik- titik data menyebar diatas dan dibawah atau disekitar angka 0 . Titik tidak berkumpul pada satu titik baik berada di titik atas saja atau berada di titim bawah saja, serta penyebaran titik-titik data tidak berpola. Dengan demikian dapat disimpulkan bahwasanya tidak terjadi masalah heterokedastisitas, sehingga model regresi yang baik dapat tercapai.

Tabel 4

\section{Uji Autkorelasi}

Sumber : Data diolah spss tahun 2020

Tabel di atas menunjukkan nilai Durbin Watson sebesar 0,960 yang berarti bahwa durbin Watson lebih besar $>$ dari -2 dan lebih kecil $<$ dari +2 yang berarti berada di antara -2 dan +2 . Dapat di simpulkan bahwa tidak terdapat autokorelasi antara residual satu pengamatan dengan pengamatan lainnya. 


\section{Uji Koefisien Determinasi}

Koefisien determinasi ialah untuk mengetahui seberapa besar kemampuan varabel bebas dalam menerangkan variabel terikat. Nilai determinasi di lihat dengan nilai Adjusted $R$ Square.

\section{Tabel 5}

Adjusted R Square

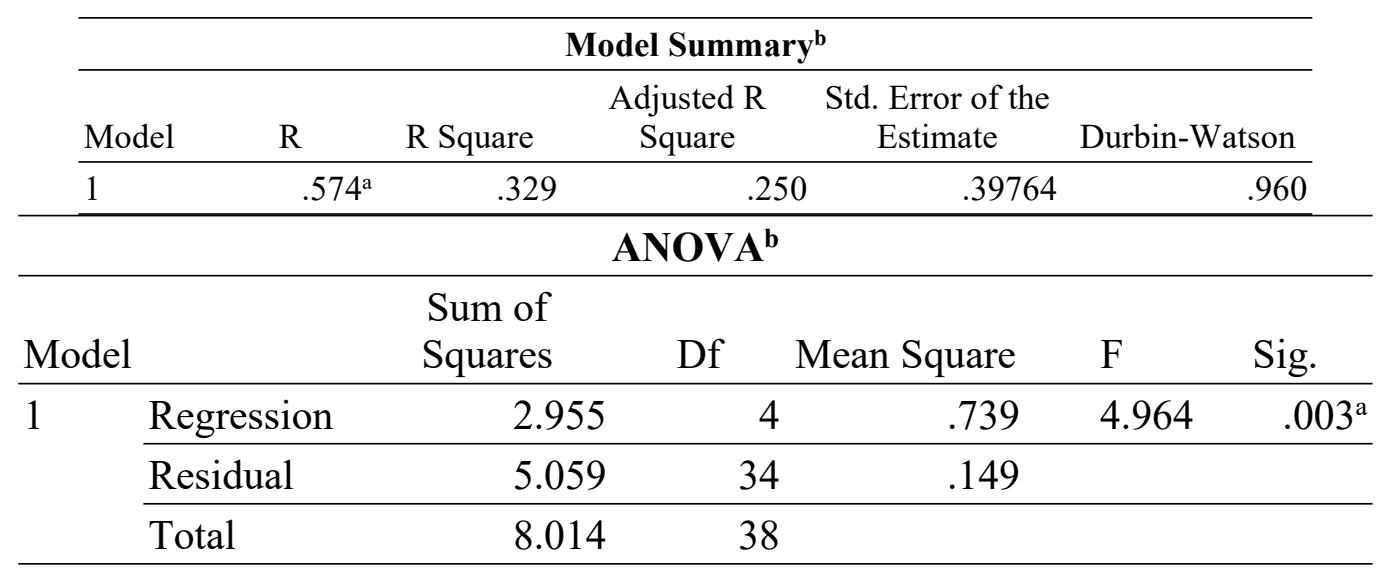

a. Predictors: (Constant), Opini Audit, PAD, Kompetisi Politik , DAU

b. Dependent Variable: E-Government

Sumber: Data diolah 2020

Berdasarkan tabel output SPSS "Model Summary" diatas, diketahui nilai koefisien determinasi atau $\mathrm{R}$ square adalah sebesar 0,369 . Nilai $\mathrm{R}$ Square 0,369 berasal dari pengkuadratan nilai koefisien korelasi atau " $R$ ", yaitu 0,607 x $0,607=0,369$. Besarnya angka koefisien determinasi ( $R$ Square) adalah 0,369 atau sama dengan 369\%. Angka tersebut mengandung arti bahwa semua variabel independen secara simultan (bersama-sama) berpengaruh terhadap variabel financial distress sebesar 36,9\%. Sedangkan sisanya $(100 \%-56,9 \%=63,1 \%)$ dipengaruhi oleh variabel lain diluar persamaan regresi ini atau variabel yang tidak diteliti.

\section{Uji F (Simultan)}

Berdasarkan hasil analisis data yang diperoleh menguji hipotesis ini, maka kemudian dilakukan uji $\mathrm{F}$ dengan membandingkan $\mathrm{F}$ hitung $\mathrm{F}$ tabel. $\mathrm{F}$ tabel dalam analisis data ini ialah $(\mathrm{k} ; \mathrm{n}-\mathrm{k})$ atau $(4 ; 40-4)=(4 ; 36)$ yang berarti nilai $\mathrm{F}$ tabel ialah 2,63 .

Berdasarkan tabel output SPSS di atas diketahui nilai Sig. adalah sebesar 0,003. Karena nilai Sig. 0,003 $<0,05$, maka menurut dasar pengambilan keputusan dalam uji $\mathrm{F}$ dapat di simpulkan bahwa hipotesis diterima atau dengan kata lain variabel kompetisi politik, PAD, DAU, dan opini audit secara simultan berpengaruh terhadap implementasi e-government. F hitung pada tabel 3.5 ialah sebesar 4,96 > F tabel 2,63 maka sesuai menurut dengan ketentuan dalam pengambilan keputusan dalam uji $\mathrm{F}$ dapat disimpulkan bahwa hipotesis diterima atau dengan kata lain seluruh variabel independen secara simultan berpengaruh terhadap implementasi $e$ government. 


\section{PEMBAHASAN HASIL PENELITIAN}

\section{Pengaruh kompetisi politik terhadap implementasi e-government}

Hasil pengujian hipotesis pertama memiliki nilai signifikan 0,85 dan koefisien sebesar -0,135. Nilai signifikan kompetisi politik besar dari $0,05(0,85>0,05)$ dapat di simpulkan bahwasanya kompetisi politik berpengaruh tidak signifikan terhadap implementasi e-government, untuk nilai koefisien yang negative dari kompetisi politik $-0,135$ yang menggambarkan bahwasanya arah dari kompetisi politik sesuai dengan arah hipotesis namun tidak mampu membuktikan secara signifikannya pengaruh kompetisi politik terhadap implementasi e-government sehingga hipotesis pertama $\left(\mathrm{H}_{1}\right)$ ditolak. Penelitian (rahim \& martani , 2016) memiliki hasil yang sama dengan penelitian ini dimana tidak di temukannya hubungan yang signifikan antara kompetisi politik terhadap pengungkapan informasi keuangan dan non keuangan. Hal ini berbeda dengan penelitian (Utami, 2017) bahwasanya dalam penelitiannya kompetisi politik tidak memiliki pengaruh dignifikan terhadap implementasi e-government. Hasil penelitian ini ternyata juga berbeda dengan penelitian (Hasibuan \& Fauzi , 2017)

Kompetisi politik yang berarah negative menjelaskan bahwasanya semakin tinggi tingkat kompetisi politik maka implementasi e-government akan dilaksanakan dengan baik oleh kepala daerah. Karena kepala daerah memiliki kecenderung untuk membuktikan tingkat kemenangannya dengan kinerjanya selama menjabat di daerah yang di pimpin. Semakin tinggi tingkat persentasi kemenangan politik di suatu daaerah, tentunya cenderung pemimpin terpilih akan membuktikan kemenangan dengan memberikan kinerja dengan sebaik-baiknya, agar tentnya dapat terpilih di periode berikutnya.

\section{Pengaruh PAD terhadap implementasi e-government}

Hasil pengujian hipotesis kedua bernilai signifikansi sebesar 0,001 dan nilai koefisien sebesar 0,028 . Nilai signifikansi dari PAD ternyata lebih kecil dari $0,05(0,001<0,05)$ yang berarti bahwasanya PAD berpengaruh signifikan terhadap implementasi e-government, nilai koefisien dari PAD yang memiliki arah positif sehingga hipotesis kedua di terima $\left(\mathrm{H}_{2}\right)$ di terima. Hal ini menggambarkan bahwasanya semakin tinggi PAD maka semakin besar pula nilai PeGi yang nantinya menunjukkan implementasi e-government yang baik.

Sejalan dengan penelitian (Utami, 2017) yang bahwasanya memiliki hasil pendapatan asli daerah memiliki pengaruh yang signifikan terhadap implementasi e-government. Penelitian ini memberikan implikasi yaitu dimana pelaksanaan e-government yang baik bahwasanya di pengaruhi oleh tingkat PAD yang tinggi. Sejalan dengan hasil penelitian ini yaitu semakin tinggi PAD maka semakin baik pelaksanakan implementasi e-government di daerah tersebut. Oleh karena itu, sebaiknya pemerintah memaksimalkan upaya untuk meningkatkan PAD agar tentunya PAD yang di peroleh dapat di alokasikan pada pelaksanaan implementasi e-government. Karena, implementasi e-government membutuhkan biaya tyang cukup besar dalam penerapannya. Pemerintah juga harus memperhatikan kembali hal-hal yang dapt meningkatkan PAD sehingga bisa meningkatkan penerapan e-government.

\section{Pengaruh DAU terhadap implementasi e-government}

Hasil pengujian hipotesis ketiga bernilai signifikansi sebesar 0,87 dengan nilai koefisien sebesar 0,000 . Nilai signifikansi dari DAU besar dari $0,05(0,879>0,05)$ yang meggambarkan bahwasanya variabel DAU berpengaruh tidak signifikan terhadap implementasi e-government untuk nilai kosfisien yang positif dari DAU yaitu 0,000 yang menjelaskan bahwasanya arah dari 
hipotesis ketiga tidak sesuai dengan arah hipotesis yang berarah negative terhadap implementasi e-government sehingga hipotesis ketiga $\left(\mathrm{H}_{3}\right)$ ditolak.

Hasil penelitian ini sejalan dengan penelitian (Jaya, 2014) yang menunjukkan bahwasanya DAU berpengaruh positif tidak signifikan terhadap pengungkapan informasi keuangan daerah melalui situs resmi pemerintah provinsi yang kemungkinan di sebabkan tidak adanya monitoring khusus yang dilakukan pemerintah pusat untuk menentukan anggaran dana perimbangan di pemerintah daerah sehingga tidak dapat mendorong pemerintah daerah dalam meningkatkan pengungkapan laporan keuangannya. Tingkat DAU yang rendah ataupun tinggi tidak mempengaruhi baik atau buruknya implementasi e-government di suatu daerah. Di karenakan, pengalokasian DAU bukan untuk meningkatkan implementasi e-government. Tingkat DAU mempengaruhi bahwasanya pemerintah daerah untuk melakukan pertanggung jawaban terhadap dana yang telah di alokasikan. Namun, salah satu bentuk pertanggung jawaban tersebut tidak di alokasikan pada peningkatan implementasi e-government.

\section{Pengaruh opini audit terhadap implementasi e-government}

Hasil pengujian keempat bernilai signifikansi sebesar 0,376 dan nilai koefisien sebesar -0,140. Nilai signifikansi dari opini audit lebih besar dari $0,005(0376>0,005)$ yang menunjukkan bahwasanya opini audit tidak berpengaruh signifikan terhadap implementasi e-government, nilai koefisien yang negative dari opini audit -0,140 yang menggambarkan bahwasanya arah dari opini audit sesuai dengan arah hipotesisi namun nyatanya tidak mampu membuktikan secara signifikan pengaruh opini audit terhadap implementasi e-government sehingga hipotesis pertama $\left(\mathrm{H}_{4}\right)$ ditolak. Hasil penelitian ini sejalan dengan penelitian (Utami, 2017) yang ternyata memiliki hasil opini audit tidak berpengaruh signifikan terhadap implementasi e-government.

Opini WTP menunjukkan bahwasanya suatu pemerintah daerah telah menyajikan laporan keuangan sesuai dengan prinsip akuntansi berterima umum yang dilengkapi informasi pendukung. Implementasi e-government tentunya membutuhkan informasi yang akurat dan lengkap untuk nantinya digunakan oleh pihak yang berkepentingan. Namun berdasarkan hasil uji signifikansi, opini audit tidak berpengaruh terhadap implementasi e-government. Hal ini menunjukkan adanya kemungkinan opini WTP ternyata tidak cukup kuat mempengaruhi suatu pemerintah daerah untuk meningkatkan penerapan e-government.

Berdasarkan hasil penelitian ini pemerintah yang memiliki opini audit WTP tidak mempengaruhi implementasi e-government dalam pemerintahan tersebut. Oleh karena itu, pemerintah tidak perlu hanya memperhatikan opini audit untuk meningkatkan implementasi $e$ government. Pemerintah juga dapat memperhatikan hal-hal lainnya selain opini audit untuk pengimplementasian e-government untuk jadi lebih baik lagi, seperti infrastruktur untuk $e$ government seperti aplikasi pengungkapan informasi jaringan di daerah tersebut, sosialisasi tentang program e-government, dan sumber daya manusia atau tenaga ahli di bidang teknologi dan informasi untuk meningkatkan penerapan e-government di pemerintahan tersebut.

\section{KESIMPULAN, KETERBATASAN DAN SARAN \\ Kesimpulan}

1. Hasil signifikansi dari kompetisi politik yaitu sebesar 0,85 dan koefisien sebesar $-0,135$. Nilai signifikan kompetisi politik besar dari 0,05 $(0,85>0,05)$ dapat di simpulkan bahwasanya kompetisi politik berpengaruh tidak signifikan terhadap implementasi e-government, untuk nilai koefisien yang negative dari kompetisi politik -0,135 yang menggambarkan bahwasanaya arah dari kompetisi politik sesuai dengan arah hipotesisi namun tidak mampu membuktikan 
secara signifikan pengaruh kompettisi politik terhadap implementasi e-government sehingga hipotesis pertama $\left(\mathrm{H}_{1}\right)$ ditolak.

2. Hasil pengujian hipotesis kedua bernilai signifikansi sebesar 0,001 dan nilai koefisien sebesar 0,028 . Nilai signifikansi dari PAD lebih kecil dari $0,05(0,001<0,05)$ yang berarti bahwasanya PAD berpengaruh signifikan terhadap implementasi e-government, nilai koefisien dari PAD yang memiliki arah positif sehingga hipotesis kedua di terima $\left(\mathrm{H}_{2}\right)$ di terima.

3. Hasil pengujian hipotesis ketiga memperoleh nilai signifikansi sebesar 0,87 dengan nilai koefisien sebesar 0,000 . Nilai signifikansi dari DAU besar dari $0,05(0,879>0,05)$ yang meggambarkan bahwasanya variabel DAU berpengaruh tidak signifikan terhadap implementasi e-government untuk nilai kosfisien yang positif dari DAU yaitu 0,000 yang menjelaskan arah dari hipotesis ketiga tidak sesuai dengan arah hipotesis yang berarah negative terhadap implementasi e-government sehingga hipotesis ketiga $\left(\mathrm{H}_{3}\right)$ ditolak.

4. Hasil pengujian keempat bernilai nilai signifikansi sebesar 0,376 dan nilai koefisien sebesar 0,140 . Nilai signifikansi dari opini audit lebih besar dari $0,005(0376>0,005)$ yang menunjukkan bahwasanya opini audit tidak berpengaruh signifikan terhadap implementasi $e$ government, nilai koefisien yang negative dari opini audit $-0,140$ yang menggambarkan bahwasanya arah dari opini audit sesuai dengan arah hipotesisi namun tidak mampu membuktikan secara signifikan pengaruh opini audit terhadap implementasi e-government sehingga hipotesis pertama $\left(\mathrm{H}_{4}\right)$ ditolak.

\section{Keterbatan penelitian}

Penelitian ini tentunya di rancang dengan sebaik-baiknya, namuntertnyata penulis menyadari bahwasanya penelitian ini masih memiliki beberapa keterbatasan yaitu sebagai berikut:

1. Penelitian ini hanya mampu menjelaskan satu variabel yang signifikan saja yaitu adalah variabel PAD dan belum mampu menjelaskan hasil signifikan dari variabel lainnya.

2. Nilai Negelkerke $\mathrm{R}^{2}$ adalah $36,9 \%$ yang berarti bahwasanya kontribusi variabel independen terhadap variabel dependen hanya $36,9 \%$. Sehingga masih banyak kemungkinan variabel lainnya yang dapat mempengaruhi variabel implementasi e-government.

\section{Saran}

1. Untuk pemerintah provinsi

Untuk pemerintah provinsi di Indonesia agar dapat memperhatikan tingkat besarnya PAD yang di peroleh, karena salah satu faktor penentu implementasi e-government adalah PAD.

2. Untuk peneliti selanjutnya

Peneliti selanjutnya tentunya di harapkan untuk menemukan variabel lainnya yang dapat mempengaruhi implementasi e-government karena mengingat persentase adanya pengaruh dari variabel lainnya cukup besar yaitu sebesar $63,3 \%$. 


\section{DAFTAR PUSTAKA}

Agustin, Henri; Arza, Fefri Indra. (2019). Potrait of Accountability and Transparency in Local Budget Management by the Regional Government in West Sumatera Province, Indonesia: An Anomaly in Digital Era. $4^{\text {th }}$ Padang International Conference on Education, Economics, Business and Accounting (PICEEBA-2). Padang. 154-166.

Agustin, Henri. (2014). Publikasi Dokumen Pengelolaan Anggaran pada WebsitePemkab/Pemkot di Propinsi Sumatera Barat. Seminar Nasional Aplikasi Teknologi Informasi (SNATI). Yogyakarta.

Al-Naimat, A. M. (2014). The Critical Success Factors For E-Government Implementation In Jordan. . Proceedings of the 4th International Conference on Computing ang Information 2013 Sarawak.

Christaens, J. (1999). Fianancial Accounting Reform in Flemish Munipalities: An Emprical Investigation. Financial Accountability \& Management, Vol. 15, pp: 21-40.

Craven, B., \& Marston, C. (1999). Financial reporting on the internet bt leading UK companies . The European Accounting Review, 8(2), 321-333.

Faud, M. R. (1999). Pengantar Akuntansi Keuangan Daerah. Bogor: Ghalia Indonesia.

Hasibuan , \& Fauzi , A. K. (2017). Pengaruh Jumlah Penduduk, Kompetisi Politik, Anggaran Belanja Modal, Total Kekayaan Daerah, dan Leverage Terhadap Transparansi Informasi Keuangan pada Situs Resmi Pemerintahan Daerah. Repositori Institusi USU.

Instruksi Presiden No.3 . (2003). Tentang kebijakan dan Starategi Nasional Pengembangan EGovernment. Republik Indonesia.

Jakarta Kompas.com. (2016, September 6). Retrieved from Ini penyebab penerapan egovernment d Indonesia belum maksimal : https://nasional.kompas.com

Jaya, J. D. (2014). Pengaruh pendapatan asli daerah, dana alokasi umum, dan belanja modal pada kelengkapan pengungkapan informasi keuangan daerah melalui situs resmi pemerintah provinsi . E-Jurnal Akuntansi Universitas Udayana, 162-179.

Jensen, M. C., \& Meckling, W. H. (1979). Theory of the Firm: Managerial Behavior, Agency Cost and Ownership Structure. Journal of Financial Economics, 305-360.

Nam, T. (2014). Determinan The Type of E-Government Use.Government information Quartely.

Publik, M. P., \& Nurmandi, A. (1997). Perkembangan Teori Tentang Publik.

rahim , w. m., \& martani , d. (2016). Analisis pengaruh tingkat akses internet, kompetisi politik, opini audit, karakteristik demografi terhadap pengungkapan informasi keuangan dan nonkeuangan website pemerintah daerah.

Rahim, W. M., \& Martani, D. (2015). Analisis Pengaruh Tingkat Akses Internet, Kopetisi Politik, Opini Audi, Karakteristik Pemda dan Karakteristik Demografi terhadap Pengungkapan Informasii keuangan dan Non-Keuangan Website Pemerintah Daerah. Perpustakaan UI.

Sipatuhur , \& Sutaryo. (2017). Faktor-Faktor Penentu Implementasi E-Government Pemerintah Daerah Di Indonesia. JURNAL RISET AKUNTANSI DAN KEUANGAN, 1393-1408.

Sipatuhur, R. S., \& Sutaryo. (2016). Faktor-Faktor Penentu Implementasi E-Government Pemerintahan Daerah di Indonesia. Simposium Nasional Akuntansi XIX Lampung.

Undang-Undang No.33. (2004). Perimbangan Keuangan antara Pemerintah Pusat dan Daerah. Undang-Undang Nomor 15 Tahun 2004 Pasal 16 Ayat 1. (n.d.).

Utami, R. D. (2017). Pengaruh Kompetisi Politik,Pendapatan Asli Daerah, dan Opini Audit Terhadap Implementasi E-Government . e-Proceeding of Management , 1588. 